\title{
BİR DÜŞÜNCE VE EYLEM İNSANI OLARAK MEHMET BEHÇET PERIMM (1896-1965)
}

\section{Ayza VARDAR2}

\begin{abstract}
$\ddot{O} z$
Bu makale, bugünkü adıyla Goltse-Delchev olan şehrin Nevrekop kasabasında 1896 yılında doğmuş, Edirne'de eğitim görmüş Mehmet Behçet Perim hakkında bilgi vermeyi amaçlamaktadır. Perim Osmanlı İmparatorluğu'nun çöküşünü yaşamış, Milli Mücadele’ye katılmış, Türkiye Cumhuriyeti’nin ilanını görmüş, Birinci ve İkinci Dünya Savaşı'nı yaşamıştır. Bulgaristan'daki Türkler’in davasına kendini adamış, hayatı boyunca verdiği eserler ve çıkardığı gazetelerle halkı bu ülküde bilinçlenmeye çağırmıştır. Konu, 2015-2016 yıllarında Kırklareli Üniversitesi’nde Bilimsel Araştırma Projeleri Koordinatörlüğü bünyesinde “Bir Bulgar Göçmeni Gazeteci, Yazar Ve Şair Mehmet Behçet Perim’in Külliyatının Oluşturulması” adıyla projelendirilmiştir. Bu projede öncelikle Mehmet Behçet Perim’in eserleri tespit edilmiş, ailesinin yardımıyla derlenmiş, bilgisayara aktarılmış ve Mehmet Behçet Perim Külliyatı oluşturulmuştur. Gazeteler ve dergiler incelemenin dışında bırakılmıştır. Makale, Perim'in hayatını ana hatlarıyla aktardıktan sonra eserlerinin kısa özetlerini vermiş ve sonuç kısmında genel değerlendirmeleri aktarmıştır.
\end{abstract}

Anahtar kelimeler: Mehmet Behçet Perim, Bulgar Türkleri, külliyat, milliyetçi Türk nesri.

\section{MEHMET BEHÇET PERIM (1896-1965) AS A THOUGHTS AND ACTION PEOPLE}

\begin{abstract}
This paper aims to give information about Mehmet Behçet Perim, who was born in the village of Satovcha near the present-day Gotse Delchev in 1896, and went to school in Edirne. Mehmet Behçet Perim was a witness to momentous events in history; he saw the downfall of the Ottoman Empire, the proclamation of the Republic, and World Wars I and II. He tried to raise awareness for the Turkish cause in Bulgaria, a case which he was devoted throughout his life and works. The content of this paper is based on the project named "Compiling the Compendium of Mehmet Behçet Perim: A Bulgarian Immigrant Journalist, Writer and Poet”, managed between the years 2015-2016 under Kurklareli University Scentific Research Coordinatorship. After Perim's works are identified and provided via his family members, they are typed; the ones which were originally written in Arabic letters were transcribed, classified according to genre and then, edited. This paper will outline his life and give short summaries of his works.
\end{abstract}

Keywords: Mehmet Behçet Perim, Turks in Bulgaria, compendium, nationalist Turkish prose.

Kırklareli Üniversitesi Bilimsel Araştırma Projeleri Koordinatörlüğü bünyesinde yürütülen 65 no’lu ve "Bir Bulgar Göçmeni Gazeteci, Yazar ve Şair Mehmet Behçet Perim’in Külliyatının Oluşturulması” başlıklı projeden üretilmiş makaledir.

2 Yard. Doç. Dr., Kırklareli Üniversitesi, Fen Edebiyat Fakültesi, Mütercim Tercümanlık Bölümü , ayzavardar@gmail.com [Makale kayıt tarihi: 29.3.2017-kabul tarihi: 12.4.2017]. 


\section{Mehmet Behçet Perim'in Hayatı ve Gazeteci Kimliği}

\subsection{Hayatı}

Mehmet Behçet Bey, 1896 yllında Selanik vilâyeti Nevrekop kasabası Şatovça köyünde doğdu. İlköğrenimi hakkında yeterince bilgi sahibi olamadığımız Mehmet Behçet Bey, orta öğrenimine Drama İdadisi’nde başladı. I. Balkan Savaşı’nın çıkması üzerine eğitimini yarım bırakarak İstanbul'a dönmek zorunda kaldı (E. Perim, 1966, s. 629). İstanbul'da zor günler geçiren Mehmet Behçet Bey, yarım kalan öğrenimini tamamlamak için tekrar Edirne'ye dönerek Edirne Sultanisi’ne başladı. I. Dünya Savaşı'nın başlaması üzerine orduya katılmak üzere İstanbul'a geldi (Deliorman, 2010, s. 83) ve İhtiyât Zâbitleri talimgâhında görevlendirildi. Savaşın içinde görev almak isteyen Mehmet Behçet Bey Çanakkale veya Kafkas Cephesi'nden birine gitmek için Genelkurmaya dilekçeler verdi. Nihayet Kafkas Cephesi'ne sevk edilen Mehmet Behçet Bey, burada üç buçuk yıl bölük komutanı olarak görev yaptı ve Ruslara karşı savaştı. Kafkas Cephesi'nden sonra bir yıl İran'da Teşkîlât-ı Mahsûsa üyesi olarak görev yapan Mehmet Behçet Bey’in görevlerinden biri Ruslara karşı savunma yapan Ali İhsan Paşa'ya Ruslar hakkında gizli bilgiler ulaştırmaktı. Bir diğer görevi ise Enver Paşa'nın onayı ile Tebriz'de bir gazete çıarmaktı. "Ahâlı̂” adı verilen bu gazeteyi İran'da sadece üç nüsha olarak çıkarabilmiştir. I. Dünya Savaşı’nın bitmesi ile İran'daki görevi sona eren Mehmet Behçet Bey, Edirne'ye dönmek üzere yola çıtı ise de ilk durağı olan Batum'da 30 Ekim 1918'de imzalanan Mondros Ateşkes Antlaşması'nın maddelerini öğrendi ve büyük bir üzüntüye kapıldı ("Mehmet Behçet Perim”, Trakya'da Yeşilyurt, 1966, s. 1; E. Perim, 1966, s. 1). Nihayet Edirne'ye dönen Mehmet Behçet Bey, "Ahâlı̂” gazetesini yeniden yayımlamaya başladı ve Trakya Yunanlılar tarafından işgal edilinceye kadar da çıkarmaya devam etti. Gazetede yazdığı yazılar ile Trakya'da bulunan Türkleri işgalcilere karşı uyarmaya çalıştı ("Mehmet Behçet Perim”, Trakya'da Yeşilyurt, 1966, s. 1). Mehmet Behçet Bey'in Millî Mücadele yanlısı bu yazıları nedeni ile “Ahâlî” gazetesi, Trakya Paşaeli Cemiyeti tarafından çıkarılan "Trakya Paşaeli” gazetesinin yanı sıra cemiyete yardımcı yayın olarak kabul edildi (Doğruöz, 2007, s. 4 2). Yunanlıların 20 Temmuz 1920'de Trakya'yı işgale başlamaları üzerine bir ay Trakya'da Yunan kuvvetleriyle çarpışan Mehmet Behçet Bey, burada bir şey yapamayacağını anlayarak mücadelesine Anadolu'da devam etmek istedi. Bu amaçla yola çıktı; fakat Uzunköprü İstasyonu'na geldiğinde Yunan askerlerinin saldırısına uğradı. Yaralanan Mehmet Behçet Bey, bir müddet Kırklareli ili Kofçaz ilçesi Taştepe köyünde saklanmak zorunda kaldı. Bütün çabalarına rağmen Anadolu'ya geçmeyi başaramadı ve mücadelesine devam edebilmek için Trakya Paşaeli Cemiyeti üyeleri gibi Bulgaristan’a geçti Bulgaristan'da kaldığı altı yıl boyunca "Ahâlı̂", "Koca Balkan” ve "Tuna Boyu” adlı gazeteleri büyük sıkıntı, tehlike ve mahrumiyetlere katlanarak yayımlamayı başardı.

1927 yllında Bulgar istihbarat makamları tarafından uğradığı sıkı takibat sonucunda gizlendiği Razgrad kasabasından elde ettiği sahte bir pasaportla Türkiye’ye dönmek zorunda kaldı. Türkiye’ye dönüşünde tekrar Edirne'ye yerleşen Mehmet Behçet Bey, "Vakit” ve "Milliyet” gazetelerinin Trakya muhabirlikleri ile mahalli gazetelerde yazı hayatına devam etti. 1929 yılındaki ekonomik bunalımın etkisi ile Türkiye'de başlayan işsizlikten nasibini alan Mehmet Behçet Bey tekrar Bulgaristan'a döndü. Burada kendisine suikast düzenlendi; mucize eseri olarak kurtuldu ve tekrar Türkiye’ye döndü. Önce Lüleburgaz Özdilek gazetesinde çalıştı. Daha sonra Tekirdağ'da bir bankada çalıştı.

Mehmet Behçet Bey, 1936 yılından itibaren kamu hizmetinde görev yaptı. 1939-1942 yılları arasında Hatay-Antakya Emniyet Müdürlüğü Siyasi Şube Şefliği, 1942-1947 Süveydiye (Saman Dağı) Nahiye Müdürlüğü, 1947-1949 Harbiye Nahiye Müdürlüğü, 1949-1951 Bedivye Nahiye Müdürlüğü görevlerinde bulundu. Son görevi İzmir Savunma Müdürlüğü’nde bulunduğu sırada, yaş haddinden altmış üç yaşında 
emekliye ayrıldı. Mehmet Behçet Bey, emekliye ayrıldıktan altı yıl sonra 22 Aralık 1965 Çarşamba günü İzmir'de hayata gözlerini kapadı.

Mehmet Behçet Bey’in oğlu Mehmet Ertuğrul Perim, Türk Kültürü Dergisindeki makalesinde babasını şu şekilde anlatmıştır:

“Kendisini tanımaya başladığı andan, İzmir'de mütevazı köşesinde hayata gözlerini kapadığı tarihe kadar bir mücadeleci olarak yaşamıştır. Onun en ilginç tarafi şüphesiz bu vasfidır. Esasen çok kere Makedonyahlara has olan bu karakter Mehmet Behçet Perim'de güzel bir örneğini bulmuştu. Tükenmez enerjisi, ölçüsüz yurtseverliği: mücadele aşkinın iki ana unsuru idi. Bu ruh onu, Aras boyunda, Ergene kenarında, kahraman Tuna boyunda, ülkü dağıtıcı ve hayatının son anına kadar mücadeleci yapmıştrr. Kemalizm’in, Yeni Türkiye için, üzerinde asla operasyon yapılmayacak bir hayat damarı olduğuna inanmıştı. İnkılâplara yürekten bağlıydı. Milletimizin hayatiyetini koruması ve ilerlemesinin, inkılâp tavizciliğ i yapmamakla mümkün olacağına tam bir inancı vardır. Atatürkçülükten başka bir millî ve sosyal inanca, bu memlekette yer olmadiğına; her şeyin onun içinde esasen var olduğuna en samimi şekilde inananlardandı. O, bir halk çocuğu olarak doğmuş, halka hizmet edebilmek aşkıyla yaşamış ve bir halk adamı olarak ölmüş̧ür. Halk arasından yetişerek halkı unutanların düştüğü bedbahtlı̆̆ uğramayan bir bahth kişi idi. Onun, kamu hizmetinde görev aldıktan sonra, tesadüfen içine girdiği idarecilik mesleğinde görev yaptığı sürece, örnek bir idareci olduğu, verdiği eserleri görenler, icraatın yakından takip edenler tarafindan hakkıyla teslim edilmiş, idari kariyerlerden yetişenlerce ise takdirle karşılanmıştır. $O$, tab'an iyi bir idareci idi. Ancak bu özelliğinin şüpheye yer brrakmayacak şekilde ortaya çıkışı, idare amirliği yaptığı esnada olmuştur. Daha ilk Dünya Harbinde başında bulunduğu bölüğü ateş hattına sürerken bu evsafi ile temayüz etmiştir. 1948 yılında, başlarında dekanları sayın Prof. Cahit Oğuzoğlu olduğu halde Hatay bölgesinde bir geziye çıkan Ankara Hukuk Fakültesi öğrencileri, bu beldenin Süveydiye (Samandağı) bucağında onun verdikleri eserleri gördükleri zaman içlerinden bir genç heyecanlanarak, 'Ben de idari kariyere intisap ederek böyle bir idareci olmak için çalşacağım' demiştir. Görev yaptığı bucaklardan ikisi hariç diğerleri ilçe haline getirilmiş, intikal devresinden sonra başka bir bucağa, tayinen ayrllirken, halk daima üzüntü duymuş ve onu örnek bir idareci olarak anmıştı" (E. Perim, 1966, s. 632-633).

\subsection{Gazeteci Kimliği}

Mehmet Behçet Bey'in basın hayatı 1913 yılında çıkarmış olduğu El-Medâris gazetesi ile başlamıştır. Bunu Balkan Savaşları sırasında yayımlanan "İslâm Dünyası", "Halka Doğru” isimli dergilerde yazdığı yazılar takip etmiştir (E. Perim, 1966, s. 629). I. Dünya Savaşı sırasında İran'da "Ahâlı̈"gazetesini yayımlamaya başlayan Mehmet Behçet Bey savaşın sona ermesi üzerine Edirne'ye dönerek burada, "Ahâlî" gazetesini çıkarmaya devam etmiştir ("Mehmet Behçet Perim”, Trakya'da Yeşilyurt, 1966, s. 1). Edirne'nin Yunanlılar tarafından işgali üzerine Bulgaristan'a geçen Mehmet Behçet Bey, burada kaldığı altı yll boyunca da gezetecilik faaliyetlerine devam etmiştir. Bulgaristan'ın Sofya ve Rahova kentlerinde "Ahâli" (1929-1922), Filibe'de "Kocabalkan" (1925), Sofya'da "Bulgaristan" (1926), Razgrat ve Plevne'de "Tuna Boyu" (1926-1927), yine Plevne'de "Mücadele" (1926) gazetelerini; Rahova'da "Altın Kalem" (1923) dergisini çlkarmıştır. Mehmet Behçet Bey’in Bulgaristan'daki en uzun soluklu gazetesi "Ahâlî" gazetesi olmuştur.

Bulgaristan'daki Türk azınlığı hakları için mücadeleye devam ederken Türkiye'de kurtuluş mücadelesi verilmekteydi. Mehmet Behçet Bey, Bulgaristan'da bulunduğu yllarda bir taraftan Bulgaristan Türkleri 
için mücadelesini sürdürürken diğer taraftan Anadolu'ya yararlı olmaya çalıştı. Ahâlî gazetesinde yazdığı makaleler ve şiirlerle bu kutsal davaya hizmet etti. Atatürk için Faruk Nafiz’ın yazdığı “Allah’ın En Büyük Kulu” başlıklı manzume, 1921 yılında Ahâlî gazetesinde yayımlandı.

Ahâli gazetesi, sadece Millî Mücadele veya Bulgaristan'da yaşanan olayları yayımlamakla sınırlı kalmamıştır. Garp ve Doğu Trakya ile ilgili haberlere de yer vermiştir. Zaman zaman şahıslar hakkında bilgiler vererek onların fotoğraflarını da yayımlamıştır. Gazetenin reklam aldığı da görülmektedir.

Perim’in çıkardığı gazetelerle ilgili belge yetersizliğinden dolayı proje kapsamında daha fazla bilgi bulunamamıştır ancak makalede Altın Kalem dergisine az da olsa yer ayrılmıştır.

\section{Eserlerin Özetleri ve Değerlendirilmesi}

Yazarın eserleri türe göre ve kronolojik olarak sıralanmıştır (romanlar, dergi, piyes, nesirler ve şiirler).

\subsection{Balkan Çiçekleri- 1938, Roman.}

Romanın başkarakteri, Akıncılar köyünün demircisi Hasan Usta’nın oğlu Demir'dir. Büyük yürekli küçük insan olarak tasvir edilen Hasan Usta ve karısı Melek'in hasretle bekledikleri tek oğulları Demir, olağanüstü zekâsı, çalışkanlı̆̆ı, ahlakı, dürüstlüğü ve daha birçok mükemmel özelliğiyle dikkatleri üstüne çeker ve onun okutulmasına karar verilir. Selanik'e atanan öğretmeninin yerine girdiği kız okulunun tarih dersinde Leyla ile karşılaşır ve birbirlerine âşık olurlar. Leyla ile imkânsız aşk yaşamaktadırlar; son kez görüşmelerinin ardından Demir, Selanik'e gitmek üzere trene biner ve bir başka istasyonda, kendi köyünden çocukluk arkadaşı Pavlina ve kardeşi Nikola ile karşılaşır. Selanik’te ortak bir çevrede geçirdikleri günlerin ardından Pavlina, Demir'e aşkını itiraf eder. Demir ise Leyla'dan başkasına bakmamaya kararlı olarak Pavlina'yı geri çevirir, öpmeyi ihmal etmeden. Bu olayın ardından ortadan kaybolan Pavlina, Drama'ya döner, Leyla'yı bulur ve ona kendi ağzından bir mektup yazdırarak Demir'e olan biteni anlatır. Demir, bu olay üzerine Leyla'yı kaybettiğine inanır. İdealist fikirleri ve liderlik vasıflarıyla öne çıkan Demir, İttihat ve Terakki ile yakınlaşır, Balkan Savaşı yıllarında da askere gider. Başta cepheye gönderilmese de, Balkan Savaşı ile doğup büyüdüğü toprakların altüst olduğunu görür, babasının şehit düştüğünü öğrenir, Leyla'dan da umudu keser ve cepheye gönüllü yazılır. Ordunun konakladığı Maraş'ta Leyla annesiyle gelip onu bulur, umudu tekrar tazelenir. Leyla, Demir'in savaştığı cephelere yakın kalmak için gönüllü hemşire olacak ve Erzurum'a tayin edilecektir, burada ise yakalandığı hastalıktan kurtulamayarak hayatını kaybeder. Yenilgi ve mütareke ile amaçsız kalan Demir, Leyla'nın yası ve öldüğüne inandığı annesinin hasretiyle köylerine döner. Burada teyzesinden, annesinin ölüm haberini alır. Ertesi gün, gece annesinin rüyasına girdiğini söyleyen Pavlina gelir evlerine. Zengin bir çeteciyle gönülsüz evlenmiştir, mutsuzdur. Leyla'nın öldüğünü Demir'den öğrenir. Kocasının evde başka çete liderleriyle buluşup kanlı planlar yaptığı bir gecenin sonunda Pavlina, Demiri eve alır, birlikte kocası ve arkadaşlarının oturduğu salona girerler. Pavlina haç çıkarırken Demir el bombası çıkarır, kendileriyle birlikte çete liderlerini havaya uçurarak son nefeslerinde Makedonya'da direnişin ateşini yakarlar. Özetten de anlaşılacağı gibi romandaki kişiler, karakter olmaktan çok arketipe yakınlar. Keskin hatlar ve siyah-beyaz ayrım dikkat çekiyor. Özellikle Demir, iyi bir erkekten beklenen tüm özellikleri üzerinde toplamışken, kötü karakterler de kötülükten başka hiçbir şey içermeyecek şekilde tasvir edilmiş. Diğer yandan, Leyla'nın hüzünlü ve uzak bir "maşuk” olmaktan başka hiçbir özelliği bulunmazken, Pavlina'ya şaşırtıcı olmayan bir biçimde fettanlık ve girişkenlik uygun görülmüş, anneler ise "ana" olmaktan öteye geçememiştir. Yazarın dili ise karakterlerinden çok daha incelikli. Tasvirlere önem veriyor ve özellikle doğayı tasvir etmeyi seçerken, doğa dışı nesnelerin tasvirlerinde de yine doğayı 
kullanıyor. Cümle uzunluklarını değiştirerek akıı bir ritim yakalamış. Romanın yazıldığı yılların dil ve sözcük seçiminin izlerini sürmek mümkün olduğu için, dönemin dil ve edebiyat anlayışına da ışık tutuyor. Savaş yıllarında insanların birbirine (1930'larda bekleneceği gibi) Bay Demir - Bayan Sıdıka diye hitap etmesi gibi anakronizm örneklerinin ise metne gölge düşürmek yerine ilginçlik kattığı söylenebilir.

\subsection{Göçmen Ahmet- 1939, Roman}

Roman, eski öğrencisi, bugün ise Tekirdağ’nn Barbaros köyünde başöğretmen olan İsmail Korkut'un defalarca yinelediği davetini, Edirne'deki kalabalık hayatından sıkıldığı için kıramayan Cevdet Yeltepe'nin köye misafir gitmesiyle başlar. Yeltepe burada, köylünün Mecnun Ahmet adını taktığı münzevi bir kişilik olan Ahmet Gültekin ile ilgilenir. Köylüden özellikle uzak duran Gültekin, Yeltepe gibi açılk fikirli bir kişiyle karşılaştı̆̆ı için memnun olur ve ahbaplıkları ilerler. Gültekin, Makedonya'dan Edirne'ye göçen bir ailenin çocuğudur ve küçük yaştan itibaren zekâsı, çalışkanlığı ile dikkat çeker. Savaş nedeniyle Edirne'den uzaklaşır, Kurtuluş Savaşı'nın ardından geri döndüğünde ise Ulviye isimli bir kıza tutulur. Alabildiğine erdemli bu kızın kötü kalpli dayısı ise, kızın bir göçmene varmasına karşı çıkarak onu bir zenginin beceriksiz oğluyla zorla evlendirmeye çalışır. Ulviye'nin kaçırma teklifini, Gültekin vazife bilinciyle reddeder ve şehirden ayrılır. Köyde Cevdet Yeltepe, İsmail Korkut ve Ahmet Gültekin uzun sohbetler, gezilerle aylar geçirir. Bu sırada Gültekin'in sağlığı kötüye gitmekte fakat kendisi tedavi olmayı reddetmektedir. Erdemli, aydın, sanatı ve edebiyatı toplumu ilerletmek için birer araç olarak gören; Türk ahlakına ve milli olana tutkuyla bağlı bir kişilik olarak tasvir edilen Gültekin, köylüyle paylaşamadı̆̆ı için kendisine "Mecnun" lakabını taktıkları fikirlerini onlara açar, Yeltepe ile aralarında kardeşlikten öte bir bağ kurulur. Bu bağın kardeşlikten öte olduğu, Yeltepe'nin oğlunun hastalı̆̆ını bildiren bir telgrafla ortaya çıkar. Gültekin, Yeltepe'ye derhal Edirne'ye gitmesini ve oğlunun başında durmasını söyler. Yeltepe gider; oğlu iyileşir fakat aklı kötüye giden Gültekin'dedir. Nitekim bir süre sonra Gültekin, oğlu iyileştiyse onu yalnız bırakmamasını rica eden bir telgraf gönderir. Yeltepe hemen gider fakat onu ölüm döşeğinde bulur. Nihayet son nefesini verdiğinde, bir süre önce ve evlenmeden ölen Ulviye'nin gönderdiği, U.G. işlemeli bir yazma ile çenesi bağlanır. Yazarın köşeli, kalın hatlı, iyiliği ve erdemi her şeyden önce Türklüğe ve milliliğe bağlayan karakterleri öne çıkmaktadır. Romandaki tüm erkek karakterler Türklüğün yüceliğine ve Cumhuriyet'in erdemlerine gönül vermiş, "iyi” ve "doğru" insanlarken, kadınlar özelliksiz ve nesne düzeyinde kalır. İyi karakterlerin bütün erdemleri şahıslarında topladıkları, kötülerin ise tepeden tırnağa ve sebepsizce kötü oldukları görülür; ara tonlara yer verilmemiştir. Yazarın eserde özellikle Ahmet Gültekin’i adeta söylevler halinde konuşturup fikirlerini etraflıca beyan ettirmesi, zaten fazla köşeli olan karakterlerle özdeşim kurmayı güçleştirmektedir. Öte yandan uzun ve canlı doğa tasvirleri romana renk ve sürükleyicilik katarken, doğa dişı varlıkların tasvirinde de doğadan yararlanılması dikkat çekicidir. Dil ve kelime tercihleri ile üzerinde durulan konular, dönemin ruhunu iyi yansitır.

\subsection{Altun Kalem Dergisi}

Mehmet Behçet Perim, 1924-1925 yılında Rahova'da çıkardı̆̆ı bu dergide 'gençlerin, halkın uyanmasına' çalıştığını açıkça ifade eder. 15 günde bir çıkan dergi, Arap Harfleriyle Ahali Matbaasında basılmıştır. 38 arasındaki sayılarına ulaşılmış dergide şiir, bilmece, deneme, İslam üzerine yazılar, sosyal hayatta görülen kimi olumsuz durumlara ilişkin fikir yazıları görülmektedir. Yahya Kemal, Cemal Konuralp, Abdülhak Hamit, Ahmet Yahya Bey gibi yazarların eserlerine yer veren dergide, okurlardan gönderilen yazılar da 'Türklüğe faydalı olmak şartıyla' yayınlanmaktadır. Derginin yayın hayatına kaç sayı devam ettiği hakkında elimizde kesin bir bilgi bulunmamaktadır. 


\subsection{Vatan Yollarinda-1923, Piyes}

Beş perdeden oluşan bir manzum piyes olan "Vatan Yollarında", İzmir Yunan işgalindeyken yazılmıştır. Millî Mücadeleye şehit veren bir Türk ailesinin hayatından bir kesit içeren oyunun dili sade ve anlatımı dramatiktir.

\subsection{Bulgaristan Müslümanları İçtimaî ve Siyasî Halleri- 1923, Fıkralar}

Bu eserinde Perim, Bulgaristan'da bulunan Müslümanların sosyal hayatlarını, Türk ve Müslüman kimlikleriyle olan bağlarının durumunu, birbirleriyle ve Bulgarlarla olan ilişkilerini incelemiş ve yaptığı eleştiriler için çeşitli çözüm önerilerini sunmuştur. Eserin sonundaysa iki küçük diyalogla bu gözlem ve düşüncelerini temsili şekilde canlandırmıştır. Eserin bölümleri sırasıyla "Bulgaristan'da İçtimaî Vaziyetimiz", "Bulgaristan'da Siyasî Vaziyetimiz", "Düşüncelerim” ve "Bulgaristan'da Nice Konuştuğumuza Dair Bir Temsil” şeklindedir. Eser çoğunlukla gözlem ve düşüncelere dayalı olduğu için yalın ve doğrudan bir anlatım tercih edilmiştir. Perim, Bulgaristan'da yaşayan Müslümanların çoğunluğunun Türk ve Müslüman kimliğinden uzaklaşıp yerel kültüre uyum gösterdiğinden yakınmaktadır. Yazar, bu uğurda giyim tarzını değiştirip şapka takanlar, çocuklarına dini eğitim aldırmayı tercih etmeyenler, gösteriş peşine düşenler, hepsinden önemlisi de dilini önemsemeyip Bulgarcayla karışı bir dil benimseyenler olduğu şeklindeki gözlemlerini dile getirmektedir. Perim bütün bu durum karşısında getirdiği önerilerde son derece milliyetçi ve aktivist bir tutum sergilemekte, ilgili halkı milli ve dini değerlere sahip çıkıp çok çalışmaya çağırmaktadır.

\subsection{Meriç'ten Tuna'ya- 1934, Nesirler}

Yazarın bu üst başlıkla yayımladığı eseri, "Balkan İlhamları, Yosunlu Çeşme" bölümü ile iki ana altbaşlı̆ga ayrılmış durumdadır. Perim bu eserinde yine kısa denemeler, anılar ve gözlemlerini aktarmıştır. Kimi yazılar on cümleyi geçmemektedir. Genelinde didaktik bir içerik bulunan yazılar sade ancak sivri bir biçemle ele alınmış, toplumsal bir bakış önde tutulmuştur. İlk bölümde "Çorbaya Tuz", "İş Bölümü”, "Bizim Vazifemiz", "İhtiyar Yemenici”, "Canlı Asansör”, "Cemiyet Adamı”, "Hayat da Bir Mektepdir”, "Vazife Aşkı”, "Memur Nezaketi”, “Köy Muallimi” gibi yazılarda topluma öncülük edecek okumuş- yazmış kimselerin yanında eğitimsiz ancak mesleğini iyi yapan, iyi terbiye almış, görgülü ya da ailesinin geleneklerini yaşatabilen insanlardan söz edilmekte, gençliğin bu karakterlerden ders almaları gerektiğine işaret edilmektedir. Yazar, "Meriç’ten Tuna’ya" altbaşlıklı makalesinde ise oğluna kendi çocukluğunun coğrafyasından sesleniyor. "Dönersek" adlı yazısında, Ahali gazetesinde yayımladığı bir yazısına karşı oluşan şikâyet ve sansür isteminden söz ediyor Perim. "Maraş’ta katliam; Adana, Tarsus ve Kilis'te cehennem yanmış, yazmayalım mı?” diye soruyor ve bunlar engellenirse gazeteciler olarak özgür olamayacaklarını, halk olarak gelişemeyeceklerini vurguluyor ve gerçekleri yazmaktan dönmeyeceğini belirtiyor.

\subsection{Adam Düştüğü Yerden Kalkar- 1935, Öyküler}

Birkaç kısa öykü, mektup ve konuşmadan meydana gelen bu kitapta yazar, romanlarında olduğu gibi küçük fakat namuslu, milli olanın erdemini kavramış insanlara yer vermiş, bu karakterlerini ise onlar gibi olmayanlara ders vermek için kullanmıştır. Balkan kökenli muhacir karakterler, savaşta altüst olan bir toplum gibi tanıdık unsurların yanında, genelde ilgilendiği tarih aralığı ve coğrafyayı değiştirip Fırat kıyısında münzevi bir hayat yaşarken bir emanetini vermek için Harun Reşid’in sarayına giden fakire yer vermiş olması dikkat çekicidir. Kitabın basım tarihi belli olmamakla birlikte, yazılardan birinde 
Cumhuriyet’ten sonraki “12 yılda" ifadesi geçtiğinden 1935 olduğu düşünülür; kullanılan sözcüklerden de Dil Devrimi'nin henüz yerleşmemiş olduğu anlaşılabilir. Yazar, romanlarındakinin aksine ve bu kitapta benimsediği öykü, mektup gibi kısa formlara uygun olarak daha yalın bir dil ve kısa cümleler tercih etmiştir, fakat kelimeleri ve cümle kurma şekilleri henüz Osmanlıca etkisinin sürdüğünü hissettirir. Kitabın sonunda yazarın okura seslenmesi ve dile getirdiği talep şöyledir: "Bulgar tarihinin birçok kısımları vardır ki bizim tarafımızdan dikkatli bir alaka ile okunmaya layıktır. Bunun ve buna benzer kitaplarımın sırasıyla meydana gelebilmesi ve millet ve memlekete bu suretle hizmet edebilmesi için şu dakikada elinizde bulunan "Adam Düştüğü Yerden Kalkar" isimli kitabın acele olarak dağılmasına kardeşçe yardımınızı bekliyorum efendim.”

\subsection{Görüişler ve Duyuşlar- 1935, Fıkralar}

Edirne'de basılan bu eserinde Perim çeşitli konulardaki fikirlerini ve bunlara ilişkin deneyimlerini anı üslubuyla kaleme almıştır. "İki Söz ve Bir Deneştirme” "Gazebi Gelmiş!”, "Dam İnsanları”, "İçki ve Kumar" "Ĕ̆leniyoruz...”, "Hakiki Bir Türk”, "Hepimiz böyle olmalıyız...”, "Soyadı Alırken...”, "İki Karanfil”, "Okuyan Türk Köylüsü”, "Vatan Vazifeleri Karşısında...”, "Bir Ziyafet”, "Randıman”, "Bugünün Gençleri”, “Gençler Giderken...”, "Bir Deneme”, "Bir Yasın Töreni”, “Asker Korkusu”, “Özlü Söz”, "İki Tel Yazısı", "Geçit Resmi Karşısında”, "Randevu”, "Okuyan Ordu”, "Kocatepe”, "İki Devir Arasında”, “Amirle Memur”, "Halef-Selef”, "Bir Ders Daha”, “Ahenk”, “Gedikliler”, "Devlet Adamı”, "Bina ve Temel”, "Eser ve İnsan”, "Söz-İş”, “İk İş”, "Bir Vecize”, “Gönül Birliği”, "Ağaç ve Adam”, "Sosyal Yardım”, "Sosyete Karşısında Tekler”, "Uyanıkların Vergisi”, "İşsizlik Karşısında”, "Esnaf”, "Esnaf Terbiyesi”, "Madrabaz”, “Acı Bir Cevap”, "Bir Muhavere ve Bir Vazife” "İnsaf”, "Vicdan Korkusu”, "Milli Asabiyet”, "Şeref Düşmanları”, “Köy ve Köylü”, “Çiftçi”, “Güzel Hayat”, “Biraz da Biz”, “Boğaz Meselesi”, "Sebep?”, "Ev Bark”, “Gurur”, "İstiklal ve İstihza”, “Önce Kendisi Bil”, "Sinir Molası”, "Sira ve Saygı (Genç Okurlara)”, "Hamid’in Dură̆ı”, "Bilmek ve Unutmamak”, “Öğretmen”, “Ulus Kızı”, "Bir Sakatlık”, "Hak”, "Yeni Nesil Karşısında”, "Görenek”, “Talihsiz Kelimeler”, "Ekmekçinin Kızı”, “Aracılık”, "Bir Tip”, "İhtiras”, "Fiskos”, "Atasözü”, "Sinıf farkı", "Yangın Var”, "Cevap”, "Kestirme Söz”, "Nazik Adam”, "Sızlanma Modası", "Hüzünlü Bir Mukayese”, "Doktor", "Bir Yılan”, "Yıkılanlara Yardım”, "Yardım Şekilleri”, "Kalleş”, "Ölüm ve Hastalık”, "Maşa”, "Çok Doğru”, "Bir Düşünce”, "Örnek Olmalıyı", "Duçe’nin Hikayesi”, "İtalyan Uçakları”, "Türkler ve Avrupalılar”... şeklinde alt başlıklarla yazılan yazılar, başlıklardan da anlaşılacağı gibi milliyetçilikten işini iyi yapmaya, çalışkanlıktan örf ve adetlerin toplum içinde uygulanmasına, Atatürk sevgisinden okuma bilinci aşlamaya çok geniş yelpazede derlenmiştir. İçlerine şiir, diyalog ve anı serpiştirilmiş yazılar beş cümleyle bir buçuk sayfa arasında değişen uzunluklardadır. Anlatıların kimi Kırklareli, Edirne ve civarında geçmektedir. Perim, özellikle toplumsal eleştirilerinde doğrudan bir dil kullanmıştır.

\subsection{Eski Yapraklar- 1942, Anılar, Öyküler, Eleştiriler}

Perim'in gündelik konulara dair yazılarından derlediği bu kitabın ilk baskısının tarihi bilinmemekle birlikte, ikinci baskının 1944 yılında yapıldığı, son baskının ise 27 Kasım 1964'e kadar tarihlere gönderme yapıldığı için 1965 ve sonrasında olduğu anlaşlmaktadır. Yazar, köşe yazısı üslubu ve kısalığında hazırladığı yazılarında milli mücadele ve birlikten Türkçe ezana ve ahenksiz müezzinlere, el dokumacılığı ve küçük işletmelerden dolmuşta pikap çaldıran "kültürsüz" kadınlara kadar çeşitli konulara değinir. Dile getirdiği sorunların çoğuna çözüm olarak milli terbiye, eğitim ve Batı medeniyetlerine ayak uydurmayı göstermesi, yazarın siyasi ve sosyal duruşu konusunda fikir verse de, dil ve millilik konusundaki düşünceleri dikkat çekicidir. Genel hatlarıyla bakıldığında yazar Dil Devrimi'ni benimser ve savunur: Hatay'da manda yönetiminin etkisiyle leblebi, domates gibi 
Türkçeleşmiş kelimeler yerine "yabancı" kelimeleri kullanan, yabancı dildeki filmler izlemeyi isteyen kişilerin çok azaldığına veya hiç kalmadığına dair umutlarını dile getirmesi, Türkçe ezanı ve ibadeti savunması bunun kanıtı sayılabilir. Ama aynı zamanda dilin "evrime” bırakılmasını istediği görülür, örnek olarak da “mebus” kelimesinin önce "saylav” yapılıp ardından "milletvekili”nde karar kılınmasının saçmalığından söz etmesi gösterilebilir. Diğer yandan, yeni karşılıkların benimsenmesi için "mesela (örneğin)" gibi yöntemlere de başvurur. Bu eserinde edebiyat okuru olmayabilecek bir kitleye de sesleneceğinin bilinciyle hareket eden yazar kolay bir anlatıma, kısa cümlelere başvurmuşsa da, doğa tasvirlerine düşkünlüğünü ortaya koyar. Bunun yanında dil ve millet bilincini aktarmaya kararlılığı, seçtiği konularda ve yazısını özenle kurgulamış olmasında kendini gösterir. Perim, bir yazar olarak kendine biçtiği görevi kitabının başındaki şu cümleyle ifade etmiştir: "Yazarın sanat ülküsü, yurt ve ulus yararına yönelmedikçe muhtaç olduğumuz toplumsal evrime, asla erişemeyiz."

\subsection{0. Çağlayanlar Bölgesi Hatay- 1943, Yankılar ve İncelemeler}

Perim’in Hatay'a olan özel hayranlığının bütün gerekçeleri bu eserde açıkça işlenmiştir. Yazar Hatay’a gazeteci olarak trenle gitmiş, gittiği günlerde henüz şehirden "Hatay Devleti” olarak söz etmiştir. Daha sonraki gözlemlerini bir günlük tutar gibi tarihiyle aktardığı durumlar olmuştur. Bunlardan biri, Hatay’ın Türkiye topraklarına katılışının kutlandığı gündür ve Perim bu günü tüm vatani duygularının gücüyle bayram havasında anlatmıştır. Şehrin tarihçesinin, coğrafi koşullarının, nüfus ve idari durumunun, siyasi öneminin haritalar ve fotoğraflarla ayrıntılı betimlemeleri Perim'in dikkatli kaleminden okunabilir. Ayrıca Perim şehrin kültürel üretimlerini, buradaki sanat ve eğitim faaliyetlerini de aktarır. Köyler, kasabalar tek tek adlarıyla sayılır ve buralardaki bitki örtüsü, tarım ve hayvancılık etkinlikleri, eski eserler açıklanır. Hatay halkının milliyetçilik, vatanseverlik, konukseverlik, yiğitlik gibi sıfatlarının üzerinde örneklerle durulur. Perim, bu kısa gezisinin sonunda Hatay'ın maddi manevi bir aşığı olarak kaleme aldığı eserinin kimi yerlerinde şiirlere yer vermiştir. Eserin sonuna doğru, Hatay'ın Türkiye topraklarına katıldıktan sonra ilk Türk valisine gelen ilk emirler bulunmaktadır. Bu kitap bire bir tanıklık etmesi açısından hem Türkiye Tarihi hem Hatay’ın şehir tarihi için önem taşıyan bir kaynak kitap niteliğindedir. Kitabın dili sade ve sürükleyici, ayrıntıları canlı, betimlemeleri öznel olmakla birlikte son derece gerçekçidir.

\subsection{Sofya Hatıraları - 1949, Nesirler, Öyküler}

Yazar, bu eserini "Yurdumun Değerli Öğretmenlerine ve Seçkin Münevverlerine" ithafiyla açar, "Kahraman Hataylılara" adar ve bu kararının altındaki sebeplerini girişteki "Kahraman Hataylılara" adlı bölümde açıllar. Kitabın diğer bölümleri; "Millî terbiye", "Belediye Seçiminde”, "Hammal Ali”, "GelirGider Meselesi”, "Vahşiler Arasında", "Nasıl Evlendim", "Hırsızlar” şeklinde başlıklara ayrılmıştır. Başlıklar yazıların konularını belirtir. Perim, Sofya'da kaldı ̆̆ı dönemde yaşadığı sosyal, toplumsal, politik olayları çeşitli gözlem, inceleme ve karşılaştırmalara dayanarak anlatmaktadır. Eserin arkasına; "İlk Fasikül İçin Yazılanlar: Kemal'den İltifat, Sofya Hatıraları, Şükrü Balcı, Bir Kitap Münasebetiyle: Salahattin Kutlu Sofya Hatıraları, Refet Rodoplu, Onlar İçin: M. Uluğ Turanlıŏlu” gibi bölümler eklenmiş, önceki basıma gelen yankılar bu şekilde eserde yerini almıştır. Yankılar genelde olumludur. Perim'in incelikli bir dille, ayrıntılı ve güçlü bir gözlemle herkesin okuyup kendine göre ders çıkarabileceği durumları kaleme aldığı yazmaktadır. Yazarın Yahya Kemal Beyatlı ile dostluğunun izlerini bu eserde görmekteyiz. Büyük şairin Perim'e yazdığı tebrik mahiyetinde bir mektup bu eserin sonunda yer almaktadır. 


\subsection{Geçit Ver Kamçı - 1958, Fıkra ve Şiirler}

Perim'in bu kitabı, "Bir Hatıra" adlı bölümle açılır. Burada Perim, bu kitabın adının nereden geldiğini açıllar. Kitabın adı, çocukluğunun ve gençliğinin geçtiği, atalarının geldiği, onu çok etkileyen Kamçı Nehri'nden ve Perim'in Bulgaristan'daki soydaşlarını cehalet ve yobazlıktan kurtarmak için yaptığı mücadeleden gelir. Sonrasında Perim, "Geçit Ver Kamç" manzumesini nerede ve hangi şartlar altında yazdığından söz eder. Kitabın ikinci bölümünde ise hepsi didaktik ve sade bir dille yazılmış on beş adet şiir bulunmaktadır. "Annem İçin”, "Mustafa Kemal Paşa'ya”, "Son Perde”, “Türk’ün Düşmanı" gibi başlıkları olan şiirlerde vatan ve millet sevgisi, manevi duyuşlar ve düşünüşler yer almaktadır. Kitaba adını veren şiir, şiirlerin bulunduğu kısmın sonunda yer almaktadır. Sonrasında ise "Gerzeli'nin Kahvesi” ve "Bulgaristan'daki Türkler” adında iki düzyazı bulunmaktadır. Perim, bu kısa yazılarda yine Bulgaristan'daki hayattan kesitler sunmuştur.

\subsection{Hayattan İlhamlar - 1962, F1kralar}

Yazarın bu eserinin sunuşunda verdiği önsöz şöyle: "Bu gösterişsiz eseri, okumaya yeni başlamış ve yüksek tahsillerini bitirmiş olanlarımız için yazdım”. Devamında Perim, bu eserde kaleme aldığ olgunluk öğütlerinin oğullarına ve okuyanlara derin bir hayat görüşü verebileceğini savunuyor. Kitabın başında, kitapla ilgili yazılmış ve yayınlanmış iki yazıya yer veriliyor. Burada kitabın içeriğinden ve biçeminden övgüyle söz ediliyor, kitapta bahsi geçen Türk'ün Türk’ten başka dostunun olamayacağı yönündeki saptamaya koşut başka yazarların yazılarına da yer veriliyor. Hatıralar ve çeşitli didaktik manzum eserlerin de bulunduğu kitaptaki bazı başlıklar şunlardır: "Susalım Yahu", "Tahsil ve Terbiye", "Muhit”, "Sabır”, “Tolerans”, “Kontrol”, “Özeniş”, “İdarecilik”, "Bir Noksanımız Daha”, "Milli Egoizm”, "Kore Zaferi”, "Hataylı". Başlıklarda genelde sözcüklerin doğrudan anlamlarını kullanan Perim, kimi zaman içeriklerde eğretilemeler kullanmış, okuru yazılanlar üzerinde düşünmeye sevk etmiştir. Her zaman toplumsal iyileşmeyi hedefleyerek yazan yazar, bu kitabındaki fikralarda da bu duyarlığından ödün vermemiştir.

\section{Sonuç}

Mehmet Behçet Perim, 1923-1962 yılları arasında Bulgaristan, İstanbul, Ankara, İzmir gibi çeşitli yerlerdeki yayınevlerinden birçok farklı türde eserleri basılan bir yazar, şair, gazeteci ve fikir insanıdır. Günümüze değin, hakkında yapılmış ciddi bir araştırma yoktur. Külliyatı dijital kaynaklara geçirilmemiş, gelecek nesillerin merakına sunulmamıştır. Bu eserleri derleyip arşivlemek, yazarın bir dönem Yunan askerlerden kaçmak için sığındığı Kofçaz kasabasına hayli yakın olan Kırklareli Üniversitesi'ndeki öğretim üyelerine nasip olmuştur.

Perim roman, öykü, deneme, oyun, şiir, fikra türlerinde eserler vermiştir. Ana konusu vatan sevgisi ve milli mücadele olmakla birlikte doğa, aşk, anne sevgisi, toplumsal düzen ve İslamiyet’in toplumdaki yanlış uygulamaları gibi birbirinden çok farklı temalara eserlerinde yer vermiştir. Eserlerinde görülen toplumsal gerçekçi yanı, yaşadığı döneminin siyasi, sosyal yapısını eserlerinde yansıtmasını sağlamıştır. Vatansever ve aktivist yapısı, Millî Mücadele'de bire bir yer almasını sağlamış, bu dönemki deneyimleri sonraki hayatını ve eserlerini etkilemiştir.

Ülke işgal altındayken bile yazmaya devam etmiş olmasından dolayı eserlerinde yaşayan tarihi görmek mümkündür. Doğduğu, okuduğu ve yaşamının önemli bir kısmını geçirdiği Trakya'ya vefa borcunu, burada Türklük bilincini oluşturmaya adayarak ödemiştir. Kendi isteğiyle orduya yazılmış, Birinci 
Dünya Savaşı'nda Kafkasya Cephesi’nde Ali İhsan Paşa'nın emri altında bölük komutanlığı yapmıştır. Daha sonra İran-Tebriz'de Teşkilat-ı Mahsusa üyesi olarak çalışmıştır. Yahya Kemal ile aralarındaki mektuplaşmalar, dönemin edebiyat çevresiyle de yakın bir ilişkisi olduğunun göstergesidir.

Perim; yazın hayatının başlarında çıkardığı Altın Kalem adlı dergisinde Arap Harfleri kullanmış, sonraki eserlerini Latin Harfleriyle vermiştir. Bu açıdan düşünüldüğünde kendisi yine Türkiye'nin önemli bir geçiş evresini yazar olarak yaşamıştır. Fikir yazılarında Türk Dil ve Yazı Devrimini genel hatlarıyla savunmuş, ancak halkın kabul etmediği ya da alışkanlıklarına ters olan uygulamaları reddetmiş, bunların başarıya kavuşamayacağını dile getirmiştir. Bu yanıyla Türkiye Cumhuriyeti’nin devrimlerini sahiplenmiş ancak nesnel eleştiriyi de bir yazar ve düşünce insanı olarak elden bırakmamıştır.

Mehmet Behçet Perim, zamanının toplumsal olaylarına seyirci kalmamış; gerek yazılarıyla gerek cephede, gerekse bir siyasi aktivist olarak toplum için, toplum yararına, inandığı ülküleri savunmuştur. Yukarıda sayılan bütün bu sebepler, eserlerinin günümüzde yaşatılmasının tarihimiz açısından önem taşıdığını kanıtlar niteliktedir.

\section{Kaynakça}

Altın Kalem Dergisi, 1923-1924. Rahova

Deliorman, A. (2010).Bulgaristan'da Türkçe Basın 1865-2009, İstanbul Büyükşehir Belediyesi.

Doğruöz, V. T.; Işım, B. (2015). Osmanlıdan Cumhuriyete Sosyo-Kültürel Siyasi Yansımalar, s. 487-511 "Milli Mücadele Döneminde Bulgaristan'da Yayımlanan Ahali Gazetesi (1920-1922)". İstanbul: Der.

Doğruöz, V. T. (2007). Milli Mücadelede Kırklareli. Kırklareli.

Perim, M. B. (1923). Bulgaristan Müslümanları İçtimai ve Siyasi Hallerimiz. Rahva: Ahali

Perim, M. B. (1923). Vatan Yollarında. Rahva: Ahali.

Perim, M. B. (1933). Adam Düştüğü Yerden Kalkar. Tekirdağ: Tekirdağ Vilayet.

Perim, M. B. (1934). Meriç’ten Tuna'ya.

Perim, M. B. (1935). Görüşler ve Duyuşlar. Edirne: İl Basımevi.

Perim, M. B. (1938). Balkan Çiçekleri. İstanbul: Akın.

Perim, M. B.. (1942). Eski Yapraklar. Antakya: İktisat.

Perim, M. B. (1943). Çağlayanlar Bölgesi Hatay. İstanbul: Cumhuriyet.

Perim, M. B. (1949). Sofya Hatıraları. Antakya: İktisat.

Perim, M. B. (1959). Geçit Ver Kamçı. Afyon: Altun Yaldız.

Perim, M. B. (1961). Göçmen Ahmet. İzmir: Karınca.

Perim, M. B. (1962). Hayattan İlhamlar. İzmir: Karınca.

Perim, E. (1966). “Kayıplar” Türk Kültürü Dergisi, Sayı:43 Mayıs, Ankara: Ayyıldız. 